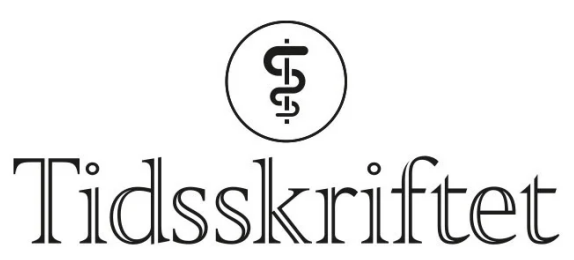

DEN NORSKE LEGEFORENING

\title{
Genetisk sammenheng mellom amyotrofisk lateral sklerose og frontotemporal demens
}

OVERSIKTSARTIKKEL

KRISTIAN VARDEN GJERDE

Kristian Varden Gjerde (f. 1985) er medisinstudent ved Universitetet i Bergen. Forfatter har fylt ut ICMJE-skjemaet og oppgir ingen interessekonflikter. Det medisinsk-odontologiske fakultet

Universitetet i Bergen

Nevrologisk avdeling

\section{OLE-BJØRN TYSNES}

Ole-Bjørn Tysnes (f. 1956) er spesialist i nevrologi. Han er avdelingssjef ved Nevrologisk avdeling, Haukeland universitetssykehus og professor II ved Klinisk institutt 1, Universitetet i Bergen. Forfatter har fylt ut ICMJE-skjemaet og oppgir følgende interessekonflikter: Han har mottatt foredragshonorar fra flere legemiddelfirmaer.

Email: ole-bjorn.tysnes@helse-bergen.no

Haukeland universitetssykehus

Nevrologisk avdeling

\section{BAKGRUNN}

Amyotrofisk lateral sklerose (ALS) er tradisjonelt blitt oppfattet som en ren motorisk lidelse, med et progredierende tap av øvre og nedre motornevroner, men uten kognitiv svekkelse eller atferdsforandringer. Det ble i 2011 påvist en genmutasjon som kan forårsake både amyotrofisk lateral sklerose og frontotemporal demens (FTD). I lys av at denne mutasjonen er oppdaget, ønsker vi å beskrive genetiske og kliniske karakteristika ved amyotrofisk lateral sklerose og frontotemporal demens.

\section{KUNNSKAPSGRUNNLAG}

Artikkelen er basert på litteratursøk i PubMed.

\section{RESULTATER}

Opptil 50\% av pasientene med amyotrofisk lateral sklerose utvikler kognitiv svekkelse, mens 3-15\% utvikler frontotemporal demens. Den nylig påviste C9ORF72-mutasjonen er til stede ved $20-50 \%$ av tilfellene av arvelig amyotrofisk lateral sklerose og muligens ved opptil $25 \%$ av sporadiske tilfeller. Mutasjonen er den vanligste genetiske årsaken til amyotrofisk 
lateral sklerose. Pasienter med $\mathrm{C}_{9} O R F_{72}$-mutasjon har tidligere sykdomsstart, kortere levetid etter diagnosetidspunktet, oftere kognisjons- og atferdsendringer samt familiær disposisjon for amyotrofisk lateral sklerose og frontotemporal demens.

\section{FORTOLKNING}

Kognitive og atferdsmessige forandringer ved amyotrofisk lateral sklerose er vanlige og kan oppstå langs et klinisk kontinuum med utvikling av frontotemporal demens over tid. Påvisning av C9Orf72-mutasjonen representerer en utfordring til vår kunnskap om og håndtering av pasienter med arvelig så vel som sporadisk amyotrofisk lateral sklerose.

Amyotrofisk lateral sklerose (ALS) er en nevrodegenerativ sykdom som rammer øvre og nedre motornevroner ( $\underline{2})$. Sykdommen forårsaker progredierende pareser og medfører død etter få år grunnet respirasjonssvikt. Frontotemporal demens (FTD) er en nevrodegenerativ lidelse karakterisert av kognitiv svekkelse, atferdsforandringer, språkforstyrrelser og personlighetsendringer. Sykdommen medfører progredierende degenerering av nevroner i frontallappen og/eller i fremre temporallapp (3).

Amyotrofisk lateral sklerose ble tidligere betraktet som en ren motorisk lidelse som ikke påvirket mentale funksjoner, men det er nå vist at denne sykdommen og frontotemporal demens er nært forbundne tilstander med overlappende genetiske, patologiske, radiologiske og kliniske karakteristika (4). I to uavhengige studier $(5, \underline{6})$ ble det nylig påvist at en mutasjon i den åpne leserammen på kromosomregion 9p21 ( $\left.C_{9} O R F 72\right)$ kan forårsake både amyotrofisk lateral sklerose og frontotemporal demens. Dette indikerer at sykdommene kan nedarves sammen.

Det gis i denne artikkelen en oversikt over amyotrofisk lateral sklerose og frontotemporal demens med særlig vekt på genetiske og kliniske karakteristika.

\section{Kunnskapsgrunnlag}

Det ble gjennomført litteratursøk i PubMed med ordene «amyotrophic lateral sclerosis» og «frontotemporal dementia». Over 100 nyere arbeider ble lest i fulltekst. Noen av disse er skjønnsmessig utvalgt som kunnskapsgrunnlag for denne artikkelen.

\section{Kliniske karakteristika}

Amyotrofisk lateral sklerose er en klinisk diagnose, basert på El Escorial-kriteriene (7.). Pasienten har selektiv affeksjon av øvre og nedre motornevroner, og bildediagnostikk eller blodprøver kan ikke gi alternative forklaringer (3). Sykdommen innebærer et progredierende tap av øvre kortikale motornevroner samt nedre motornevroner i hjernestammen og i ryggmargens forhorn (3).

Ved på øvre motornevronskade er de kliniske funn hyperrefleksi, spastisitet og inverterte plantarreflekser. De kliniske funn ved nedre motornevronskade er muskelatrofi, fascikulasjoner og kraftsvekkelse (3). Bulbære symptomer som tale- og svelgevansker er vanlig ved både øvre og nedre motornevronaffeksjon.

Frontotemporal demens er en klinisk diagnose basert på Neary-kriteriene (모). Den kan inndeles i tre hovedtyper. Den frontale varianten (fvFTD), som så langt er hyppigst assosiert med amyotrofisk lateral sklerose (4), er kjennetegnet av atferds- og personlighetsendringer. Pasientene viser ofte dyssosial atferd, manglende innsikt, emosjonell likegyldighet, svekket oppmerksomhet og redusert planleggingsevne. Ved nevroradiologiske unders $ø$ kelser er det typisk bilateral atrofi i frontallapp og fremre temporallapp (4,9.). 
Den andre hovedtypen av frontotemporal demens er progredierende ikke-flytende afasi (PNFA), som er karakterisert av en ekspressiv språkforstyrrelse. Pasientene har ordletingsvansker, men relativt godt bevart ordforståelse. Nevroradiologiske undersøkelser viser atrofi spesielt i venstre frontotemporalregion (9.).

Semantisk demens (SD), en sammensatt oppfatningsforstyrrelse, er den tredje hovedtypen av frontotemporal demens. Pasientene forstår ikke lenger ordenes mening og kan av og til ikke gjenkjenne ansiktsuttrykk. Typiske nevroradiologiske funn er utbredt atrofi særlig av venstre temporalcortex (9).

Kognitiv og atferdsmessig dysfunksjon ved amyotrofisk lateral sklerose kan oppstå langs et klinisk kontinuum, rangert fra mild til moderat svekkelse og videre til frontotemporal demens (4). Strong og medarbeidere har utarbeidet en diagnostisk guide hvor amyotrofisk lateral sklerose med mild kognitiv svekkelse (ALSci) og amyotrofisk lateral sklerose med mild atferdsforstyrrelse (ALSbi) representerer pasienter med kognisjons- og atferdsendringer som ikke tilfredsstiller demenskriteriene (10). Pasienter med frontotemporal demens kan likeledes ha symptomer på motornevronsykdom (FTD-MND) uten at de tilfredsstiller kriteriene for amyotrofisk lateral sklerose. Forenklet kan man tenke seg at frontotemporal demens representerer den ene ytterkanten av et sykdomsspekter og amyotrofisk lateral sklerose den andre. Med ALSci, ALSbi og frontotemporal demens med motornevronsykdom som begynnende overlappingssyndromer kan man se et spektrum av kliniske bilder med progredierende pareser eller demens som ytterpunkter (4). (fig 1 ).

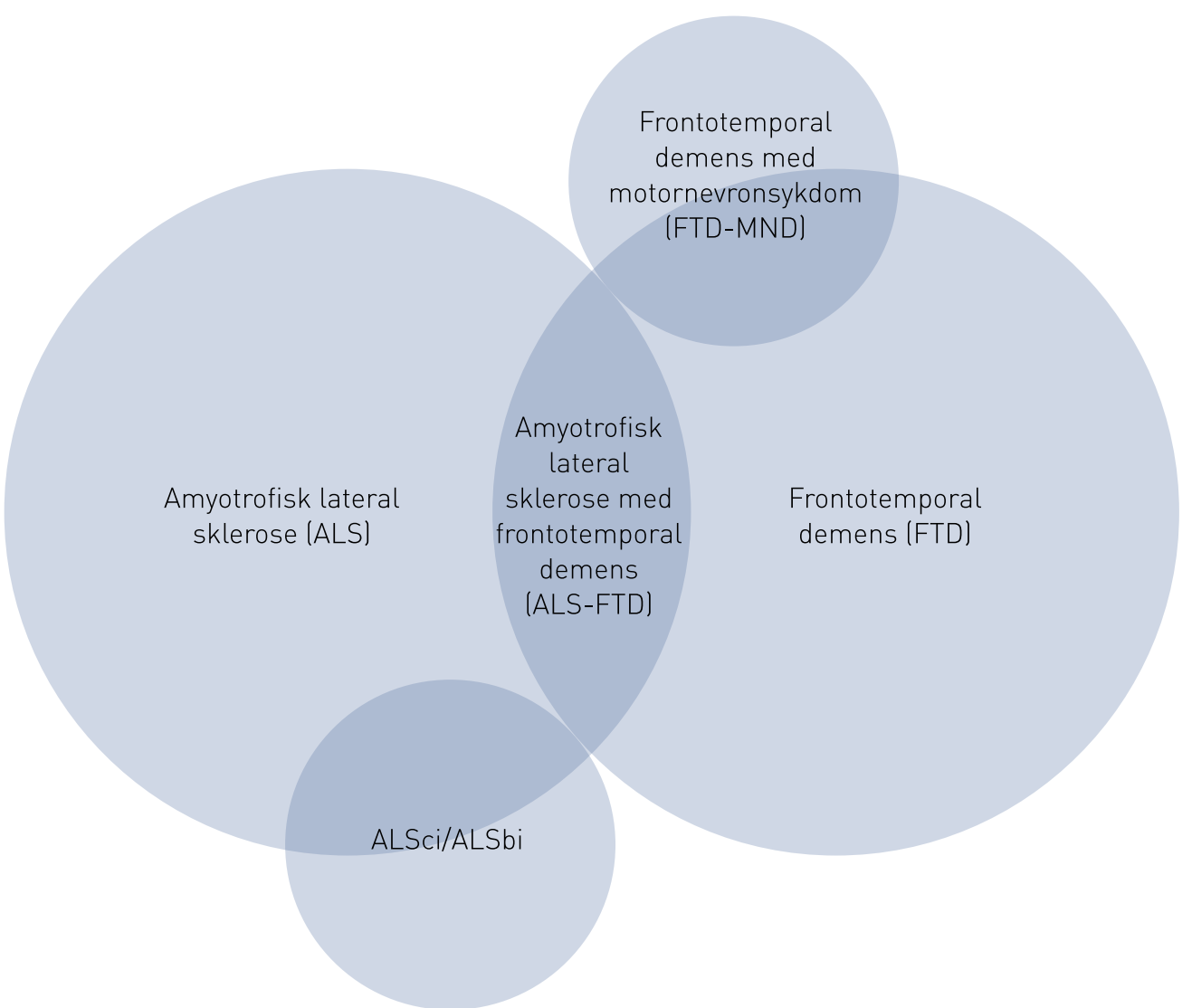

Figur 1 Kognitive og atferdsmessige forandringer ved arvelig amyotrofisk lateral sklerose (ALS) kan oppstå langs et klinisk kontinuum. Det kan rangeres fra amyotrofisk lateral sklerose med mild til moderat frontal svekkelse og videre til frontotemporal demens (FTD). ALSci (ALS med mild kognitiv svekkelse) og ALSbi (ALS med mild atferdsforstyrrelse) representerer pasienter med kognisjons- og atferdsendringer som ikke tilfredsstiller demenskriteriene, men hvor man over tid kanskje kan forvente utvikling til frontotemporal demens. Tilsvarende kan være tilfellet for pasienter med frontotemporal demens med symptomer på motornevronsykdom (FTD-MND) som ikke tilfredsstiller ALSkriteriene (4). Omtrent $15 \%$ av dem med frontotemporal demens har et 
overlappingssyndrom med amyotrofisk lateral sklerose og oppfyller diagnostiske kriterier for denne sykdommen (3). Amyotrofisk lateral sklerose og frontotemporal demens fremstår nå som beslektede tilstander med overlappende genetiske, patologiske, radiologiske og kliniske karakteristika (4)

Nevrodegenerasjon ved amyotrofisk lateral sklerose med frontotemporal demens er ikke begrenset til motornevroner og motorisk cortex, også prefrontal cortex og/eller fremre temporallapp kan være affisert (4). I en studie av pasienter med amyotrofisk lateral sklerose ble det rapportert at kognisjons- og atferdsendringer ved nevropsykologisk testing og karakteristiske MR-forandringer i ikke-motorisk cortex var signifikant assosiert med C9ORF72-mutasjon (11).

Ved familiær disposisjon for amyotrofisk lateral sklerose eller frontotemporal demens var det en enda høyere prediktiv verdi for tilstedeværelse av mutasjonen. Pasienter med amyotrofisk lateral sklerose med mutasjonen hadde $ø \mathrm{kt}$ sannsynlighet for å ha en slektning med en annen dominant arvelig nevrodegenerativ sykdom, som oftest frontotemporal demens $(\underline{11}, \underline{12})$. Dette viser at en grundig slektsanamnese er viktig i diagnostikken av disse sykdommene.

\section{Epidemiologi}

Amyotrofisk lateral sklerose har en insidens på ca. 2 per 100 ooo per år, for frontotemporal demens er insidensen 3-4 per 100 ooo per år (2 2 . Median debutalder hos pasienter med

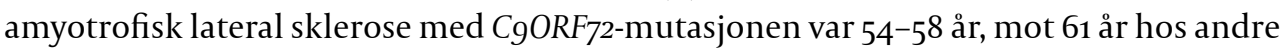
med sykdommen $(\underline{11}, 13,14)$. Median overlevelse er tre år fra symptomstart hos pasienter med amyotrofisk lateral sklerose (15), men i to studier var det en overlevelsestid på mellom 19 og 24 måneder ved amyotrofisk lateral sklerose med frontotemporal demens $(15, \underline{16})$. I to andre studier $\left(13,17\right.$.) var bulbær sykdomsstart hyppigere hos $C_{9} O R F 72$-mutasjonsbærerne, og dette var assosiert med tidlig demensutvikling (13).

Arvelig amyotrofisk lateral sklerose utgjør 5-10\% av tilfellene, og $C_{9} O R F 72$-mutasjonen er til stede hos $20-50 \%$ av disse, avhengig av studiepopulasjon (3,11). Ved sporadisk sykdom kan mutasjonen identifiseres hos 4-21\% (5, $\underline{6})$.

Frontotemporal demens er hereditær i 40-50\% av tilfellene. Både amyotrofisk lateral sklerose og frontotemporal demens har nesten alltid en autosomalt dominant arvegang (3). Omtrent $15 \%$ av pasientene med frontotemporal demens har et overlappingssyndrom med amyotrofisk lateral sklerose og oppfyller de diagnostiske kriterier for denne i løpet av sykdomsutviklingen, mens en større andel pasienter har tegn på motornevronaffeksjon uten å oppfylle kriteriene (FTD-MND) (3).

Mild kognitiv svekkelse, kjennetegnet av eksekutiv dysfunksjon (묘), kan påvises hos mellom $36 \%$ og $51 \%$ av pasienter med amyotrofisk lateral sklerose $(\underline{19}, \underline{20})$, mens 3-15\% utvikler et kognitivt og atferdsmessig funksjonstap av en alvorlighetsgrad som tilfredsstiller kriteriene for frontotemporal demens $(\underline{4}, \underline{20})$. Pasienter med amyotrofisk lateral sklerose og kognitiv svekkelse har $ø$ kt risiko for å bli ikke-samtykkekompetente. Det er derfor viktig å diagnostisere disse i et tidlig stadium $(3,4, \underline{4}$ ).

\section{Genetiske årsaker}

Autosomale mutasjoner som årsak til amyotrofisk lateral sklerose har vært kjent i en årrekke. Mest kjent er mutasjoner i genet for superoksiddismutase (SOD1-mutasjoner), som ble oppdaget i 1993 (21) og som ligger bak ca. $20 \%$ av de hereditære tilfellene og $1-3 \%$ av de sporadiske (22). En rekke andre sjeldnere mutasjoner er også påvist å kunne forårsake arvelig amyotrofisk lateral sklerose (e-tab 1). 


\section{Tabell 1}

Oversikt over noen av de hyppigste gener som affiseres og kan forårsake arvelig amyotrofisk lateral sklerose (2)

\begin{tabular}{|lllr|}
\hline Gen & Locus & Protein & $\begin{array}{c}\text { Frekvens (prosentandel av } \\
\text { affiserte) }\end{array}$ \\
\hline C9ORF72 & $9 \mathrm{p} 21.2$ & Åpen leseramme 72 på kromosom 9 & $23-47$ \\
\hline SOD1 & $21 \mathrm{q} 22.1$ & Superoksiddismutase (Cu-Zn) & 20 \\
\hline FUS & $16 \mathrm{p} 11.2$ & RNA-bindende protein FUS & $1-5$ \\
\hline TARDBP & $1 \mathrm{p} 36.2$ & TAR-DNA-bindende protein TDP-43 & $1-5$ \\
\hline ANG & $14 \mathrm{q} 11.2$ & Angiogenin & $<1$ \\
\hline VCP & $9 \mathrm{p} 13$ & Valosininnholdende protein & $<1$ \\
\hline OPTN & $10 \mathrm{p} 15$ & Optinevrin & $<1$ \\
\hline UBQLN-2 & Xp11 & Ubiquillin-2 & $<1$ \\
\hline ATXN-2 & $12 \mathrm{q} 24$ & Ataksin-2 & $<1$ \\
\hline
\end{tabular}

Det ble nylig påvist at en heksanukleotidrepetisjonsekspansjon (en ekspansjon med økt antall repetisjoner av seks nukleotider (GGGGCC)) i intron 1 av $C 9 O R F 72$-genet på kromosom 9p21.2 kan forårsake amyotrofisk lateral sklerose $(\operatorname{tab} 2)(5, \underline{6}, \underline{11}, 13, \underline{14}, \underline{23})-(\underline{25})$, med en kombinert amyotrofisk lateral sklerose-frontotemporal demens-fenotype som den hyppigste kliniske presentasjonsformen $(5, \underline{6})$. Mutasjonsfrekvensen hos pasienter med overlappingssyndrom er i flere studier rapportert til å være mellom $48 \%$ og $86 \%(\underline{11}, \underline{14}, \underline{2} 3$, 26). Pasienter med amyotrofisk lateral sklerose, amyotrofisk lateral sklerose med frontotemporal demens eller frontotemporal demens hadde et varierende antall heksanukleotidrepetisjoner (estimert til 700-16oo hos fire pasienter i en studie). Det maksimale antallet repetisjoner i kontrollgruppen var $23(\underline{6})$.

\section{Tabell 2}

Oversikt over prosentvis frekvens av $\mathrm{C}_{9} \mathrm{ORF}_{22}$-mutasjonen i ulike populasjoner av pasienter med amyotrofisk lateral sklerose og frontotemporal demens

\begin{tabular}{|c|c|c|c|c|}
\hline Studier & Populasjon & $\begin{array}{c}\text { Arvelig } \\
\text { amyotrofisk } \\
\text { lateral sklerose } \\
\text { (prosentandel } \\
\text { med CORF72- } \\
\text { mutasjon) }\end{array}$ & $\begin{array}{c}\text { Sporadisk } \\
\text { amyotrofisk lateral } \\
\text { sklerose } \\
\text { (prosentandel med } \\
\text { CORF72-mutasjon) }\end{array}$ & $\begin{array}{c}\text { Frontotemporal } \\
\text { demens (totalt) } \\
\text { (prosentandel } \\
\text { med CORF72- } \\
\text { mutasjon) }\end{array}$ \\
\hline $\begin{array}{l}\text { Renton og } \\
\text { medarbeidere (5) }\end{array}$ & Finland & 46,0 & 21,1 & 29,3 \\
\hline $\begin{array}{l}\text { Dejesus-Hernandez } \\
\text { og medarbeidere } \\
\text { (6) }\end{array}$ & Nord-Amerika & 23,5 & 4,1 & 14,7 \\
\hline $\begin{array}{l}\text { Stewart og } \\
\text { medarbeidere (13) }\end{array}$ & Canada & 27,4 & 3,6 & 22,7 \\
\hline
\end{tabular}




\begin{tabular}{|llccc|}
\hline & Arvelig & $\begin{array}{c}\text { Amyotrofisk } \\
\text { ateral sklerose } \\
\text { (prosentandel } \\
\text { med CORF72- } \\
\text { mutasjon) }\end{array}$ & $\begin{array}{c}\text { Sporadisk } \\
\text { amotrofisk lateral } \\
\text { sklerose } \\
\text { (prosentandel med } \\
\text { CORF72-mutasjon) }\end{array}$ & $\begin{array}{c}\text { Frontotemporal } \\
\text { demens(totalt) } \\
\text { (prosentandel } \\
\text { med CORF72- } \\
\text { mutasjon) }\end{array}$ \\
\hline $\begin{array}{l}\text { Studier } \\
\text { Gijselinck og } \\
\text { medarbeidere (14) }\end{array}$ & Belgia & 47,0 & 5,0 & 20,0 \\
\hline $\begin{array}{l}\text { Boeve og } \\
\text { medarbeidere (23) }\end{array}$ & USA & 24,0 & 14,7 & 19,4 \\
\hline $\begin{array}{l}\text { Majounie og } \\
\text { medarbeidere (24) }\end{array}$ & Ulike regioner & 39,3 & 7,0 & 30,8 \\
\hline $\begin{array}{l}\text { Byrne og } \\
\text { medarbeidere (11) }\end{array}$ & Irland & 41,0 & 5,0 & \\
\hline $\begin{array}{l}\text { Cooper-Knock og } \\
\text { medarbeidere (25) }\end{array}$ & England & 43,0 & 7,0 & \\
\hline
\end{tabular}

Det er flere mulige mekanismer som kan forklare hvordan en

heksanukleotidrepetisjonsekspansjon forårsaker sykdom. Ett alternativ er at reduserte nivåer av RNA-transkript kan affisere proteintranslasjon og forårsake tap av proteinfunksjon. Et annet alternativ er at RNA-transkript som inneholder repetisjonsekspansjonen kan aggregeres i cellekjernen og/eller i cytoplasma og sekvestere RNA-bindende proteiner, noe som vil kunne medføre feilregulering av mRNA-spleising (므).

TAR-DNA-bindende protein (TDP-43) er et slikt RNA-bindende protein. Nevropatologisk er $\mathrm{C}_{9} \mathrm{ORF} 72$-mutasjonen assosiert med akkumulasjon av inklusjonslegemer bestående av ubikvitinert TDP-43 i nevronenes cytoplasma (227.). TDP-43-akkumulering er funnet både ved sporadisk og hereditær amyotrofisk lateral sklerose samt ved arvelig frontotemporal demens (207.). Opphopning av proteinet kan være toksisk for nervecellen, og dette fremstår

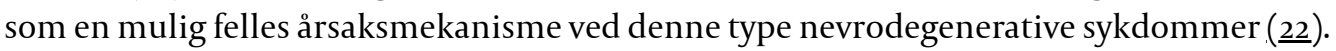
Murray og medarbeidere demonstrerte at alle tilfellene av amyotrofisk lateral sklerose med

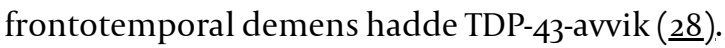

Pasienter med $\mathrm{C}_{9} \mathrm{ORF} 72$-mutasjonen får imidlertid ikke bare TDP-43-positive inklusjoner i nevronenes cytoplasma. Det er også rapportert p62-positive, TDP-43-negative, cytoplasmatiske inklusjonslegemer i cerebellum, hippocampus og frontal cortex $(\underline{13}, \underline{26})$. En studie viste at funn av slike inklusjoner i hippocampus var en relativt pålitelig indikator for tilstedeværelse av $\mathrm{C}_{9} O R F_{72}$-mutasjonen (25).

Det ubikvitinbindende proteinet p62 har som funksjon å merke proteiner for degradering via ubikvitinproteasomsystemet (UPS) og/eller autofagocytose, og p62 degraderes selv av sistnevnte. TDP-43 blir degradert av begge disse systemene, og det er vist at overekspresjon av p62 reduserer TDP-43-akkumuleringen (29.). En mulig forklaring på tilstedeværelsen av disse inklusjonslegemene kan derfor være feil i proteindegraderingssystemene som følge av proteinforandringer forårsaket av $\mathrm{C}_{9} O \mathrm{RF}_{72}$-mutasjonen (3ㅇ) .

Det er rapportert i flere studier at $\mathrm{C}_{9} O R F 72$-mutasjonen er den vanligste genetiske årsaken til både arvelig og sporadisk amyotrofisk lateral sklerose $(5, \underline{6}, \underline{11}, \underline{13}, \underline{14}, \underline{23})-(\underline{25})$ (tab 2$)$. Mutasjonen er til stede i en tredel av europeiske hereditære tilfeller av sykdommen. Det er bare GRN-mutasjoner som er en vanligere årsak til arvelig frontotemporal demens $(\underline{6}, \underline{14})$. C9ORF72-mutasjonen gjør at hovedgruppen av hereditær amyotrofisk lateral sklerose nå kan kategoriseres som en nukleotidrepetisjonssykdom (sammen med blant annet Huntingtons sykdom, dystrophia myotonica 1 og 2 og flere spinocerebellære ataksier)(므).

\section{Diskusjon}


I alle de inkluderte studiene der $\mathrm{C}_{9} \mathrm{ORF} 72$-mutasjonen ved amyotrofisk lateral sklerose eller frontotemporal demens omtales, gjennomførte man screening av pasienter og kontrollpersoner for tilstedeværelse av heksanukleotidrepetisjonsekspansjon med en «repeat-primed» PCR-metode $(5, \underline{6}, \underline{11}, \underline{13}, \underline{14}, \underline{2} 3)-(\underline{2} 5)$. En begrensning i studiene var nettopp bruk av denne metoden, som gir nøyaktig identifikasjon av opptil 6o repetisjoner i ekspansjonen, men ikke kan angi den riktige størrelsen på repetisjonsekspansjonen. Southern blotting av større pasientgrupper er derfor nødvendig for å kunne avgjøre dette (5). Det er foreløpig usikkert hvordan repetisjonslengden påvirker sykdomsrisikoen og det kliniske bildet (tidspunkt for symptomdebut og utvikling av symptomer) (11, 12).

Den angitte frekvensen av $\mathrm{C}_{9} O R \mathrm{R}_{2}$-mutasjonen ved sporadisk amyotrofisk lateral sklerose er variabel. Mens det i to studier $(\underline{6}, \underline{14}$.) ble rapportert en frekvens på henholdsvis 4,1\% og 5 \%, ble det i en tredje studie (5) rapportert en frekvens på 21,1\%. Forskjellen i frekvens kan kanskje forklares med mangelfull slektsanamnese eller ulik befolkningssammensetning.

Flere studier viser at sykdommen starter tidligere i senere generasjoner $(\underline{14}, \underline{17}, \underline{2} 3, \underline{26})$. Dette kan tyde på at antallet repetisjoner av heksanukleotidsekvensen øker i påfølgende generasjoner, slik man kan se ved trinukleotidrepetisjonssykdommer (므). Det er rapportert at enkelte $\mathrm{C}_{9} O R F_{72}$-mutasjonsbærere overlevde inn i sitt niende tiår uten symptomutvikling (1ㅡ). Dette kan indikere at mutasjonen har redusert eller variabel penetrans eller at sykdommen kan debutere sent $(\underline{11}, \underline{2} 3)$. Det er også mulig at penetransen bare er komplett sent i livsløpet. Ifølge Majounie og medarbeidere hadde repetisjonsekspansjonen ingen penetrans hos bærere som var under 35 år, den hadde $50 \%$ penetrans hos bærere som var 58 år, og nesten full penetrans hos bærere som var ca. 80 år (24).

C9ORF72-mutasjonen er, sammen med SOD1-mutasjoner, den hyppigste kjente mutasjonen som kan medføre arvelig amyotrofisk lateral sklerose (13). Sykdomsmekanismene er forskjellige, da SOD1-mutasjoner forårsaker motornevrontap ved at SOD1 akkumuleres i

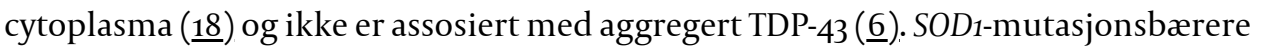
presenterer seg ofte klinisk med affeksjon av nedre motornevron, mens $\mathrm{CgORF}_{92-}$ mutasjonsbærere ofte har kombinert øvre og nedre motornevronaffeksjon samt bulbær sykdomsstart (13). Tilfeller av amyotrofisk lateral sklerose med SOD1-mutasjoner skiller seg således både klinisk og nevropatologisk fra andre genetiske og sporadiske tilfeller av sykdommen.

Genmutasjoner som man ser ved arvelig amyotrofisk lateral sklerose, er også beskrevet i sporadiske tilfeller. 90-95\% av pasientene har ikke sykdommen i familien. Genetiske forandringer oppstår tilsynelatende fra nye mutasjoner, hvorav $C_{9} O R F 72$-mutasjonen er den hyppigste (5). Mangelfull slektsanamnese og tidlig død av andre årsaker i forutgående generasjoner kan imidlertid medføre at arvelige tilfeller fremstår som sporadiske (2ㄱ.). Sykdomsrisikoen for slektninger av pasienter med sporadisk amyotrofisk lateral sklerose og sporadisk frontotemporal demens kan derfor tenkes å være vesentlig forskjellig fra risikoen i normalbefolkningen på grunn av den relativt hyppige forekomsten av $\mathrm{C}_{9} \mathrm{ORF} 72$ mutasjonen blant disse pasientene. Risikoen for mutasjonsbærere uten slektsanamnese som inneholder amyotrofisk lateral sklerose og/eller frontotemporal demens er estimert til å være mellom $4 \%$ og $7 \%$ (31).

Det er vist at $\mathrm{C}_{9} \mathrm{ORF} 72$-genet kan være ustabilt $(5, \underline{6})$. Dette kan ha betydning for mutasjonsbærere med sporadisk amyotrofisk lateral sklerose, der en tilsynelatende tilfeldig sykdomsopptreden kan være forårsaket av tilfeldig økning i antall repetisjoner (5). En annen mulig forklaring er at sporadiske tilfeller av amyotrofisk lateral sklerose kan oppstå fra mutasjoner som skjer etter befruktningen. Sykdommen starter fokalt i et lite antall celler, for eksempel i ett motornevron, for deretter å spre seg til nærliggende motornevroner. Mutasjonen oppstår i en enkeltcelle som nedarves i alle datterceller av denne cellen og forårsaker genetisk mosaisisme. Det er foreløpig ingen sikker kunnskap om rollen somatiske mutasjoner har i utviklingen av sporadisk amyotrofisk lateral sklerose (32).

\section{Konklusjon}


Det ble nylig påvist en genmutasjon på kromosomregion 9p21 som nevropatologisk hovedsakelig er assosiert med TDP-43-akkumulering. Klinisk representerer den ofte en kombinasjon av amyotrofisk lateral sklerose og frontotemporal demens. Mutasjonen er den vanligste genetiske årsaken til amyotrofisk lateral sklerose, uavhengig av studiepopulasjon. Pasienter med $C_{9} O R F_{72}$-mutasjonen er kjennetegnet av tidligere sykdomsstart, $\varnothing \mathrm{kt}$ risiko for demensutvikling og redusert overlevelsestid.

Mye taler for at kognisjons- og atferdsforandringer ved amyotrofisk lateral sklerose kan oppstå langs et klinisk kontinuum med risiko for utvikling av frontotemporal demens over tid. Opptil 50\% av pasientene med amyotrofisk lateral sklerose utvikler en frontal svekkelse, mens en mindre andel utvikler frontotemporal demens.

Den høyeste prediktive sannsynligheten for tilstedeværelse av $C_{9} O R F 72$-mutasjonen var en familiær disposisjon for amyotrofisk lateral sklerose eller frontotemporal demens. Dette viser at en grundig slektsanamnese er viktig i diagnostikken av disse sykdommene.

Basert på en studentoppgave ved Medisinsk-odontologisk fakultet, Universitetet i Bergen (1).

\section{HOVEDBUDSKAP}

Opptil 50\% av pasientene med amyotrofisk lateral sklerose utvikler kognitiv svekkelse, mens 3-15\% utvikler frontotemporal demens

$\mathrm{C}_{9} O R F 72$-mutasjonen er den vanligste genetiske årsaken til amyotrofisk lateral sklerose og amyotrofisk lateral sklerose med frontotemporal demens

Pasienter med $\mathrm{C}_{9} \mathrm{ORF} 72-\mathrm{mutasjonen} \mathrm{har} \mathrm{tidligere} \mathrm{sykdomsstart,} \varnothing \mathrm{kt}$ risiko for demensutvikling og redusert overlevelsestid

\section{LITTERATUR}

1. Gjerde KV. Ny mutasjon kobler sammen ALS og FTD. Særoppgave. Bergen: Det medisinskodonotologisk fakultet, Universitetet i Bergen, 2012.

2. Robberecht W, Philips T. The changing scene of amyotrophic lateral sclerosis. Nat Rev Neurosci 2013; 14: 248-64. [PubMed] [CrossRef]

3. Lomen-Hoerth C. Clinical phenomenology and neuroimaging correlates in ALS-FTD. J Mol Neurosci 2011; 45: 656-62. [PubMed] [CrossRef]

4. Zago S, Poletti B, Morelli $C$ et al. Amyotrophic lateral sclerosis and frontotemporal dementia (ALSFTD). Arch Ital Biol 2011; 149:39-56. [PubMed]

5. Renton AE, Majounie E, Waite A et al. A hexanucleotide repeat expansion in $\mathrm{C}_{9} \mathrm{ORF}_{72}$ is the cause of chromosome 9p21-linked ALS-FTD. Neuron 2011; 72: 257-68. [PubMed] [CrossRef]

6. DeJesus-Hernandez M, Mackenzie IR, Boeve BF et al. Expanded GGGGCC hexanucleotide repeat in noncoding region of C9ORF72 causes chromosome 9p-linked FTD and ALS. Neuron 2011; 72: 245-56. [PubMed] [CrossRef]

7. Brooks BR, Miller RG, Swash M et al. El Escorial revisited: revised criteria for the diagnosis of amyotrophic lateral sclerosis. Amyotroph Lateral Scler Other Motor Neuron Disord 2000; 1: 293-9. [PubMed] [CrossRef]

8. Neary D, Snowden JS, Gustafson L et al. Frontotemporal lobar degeneration: a consensus on clinical diagnostic criteria. Neurology 1998; 51:1546-54. [PubMed] [CrossRef]

9. Snowden J, Neary D, Mann D. Frontotemporal lobar degeneration: clinical and pathological relationships. Acta Neuropathol 2007; 114:31-8. [PubMed] [CrossRef]

10. Strong MJ, Grace GM, Freedman M et al. Consensus criteria for the diagnosis of frontotemporal cognitive and behavioural syndromes in amyotrophic lateral sclerosis. Amyotroph Lateral Scler 20o9; 
11. Byrne S, Elamin M, Bede P et al. Cognitive and clinical characteristics of patients with amyotrophic lateral sclerosis carrying a C9orf72 repeat expansion: a population-based cohort study. Lancet Neurol 2012; 11: 232-40. [PubMed] [CrossRef]

12. Andersen PM. Mutation in C9orf72 changes the boundaries of ALS and FTD. Lancet Neurol 2012; 11: 205-7. [PubMed] [CrossRef]

13. Stewart H, Rutherford NJ, Briemberg $\mathrm{H}$ et al. Clinical and pathological features of amyotrophic lateral sclerosis caused by mutation in the $\mathrm{C}_{9} \mathrm{ORF}_{72}$ gene on chromosome 9p. Acta Neuropathol 2012; 123: 409-17. [PubMed] [CrossRef]

14. Gijselinck I, Van Langenhove T, van der Zee J et al. A C9orf72 promoter repeat expansion in a Flanders-Belgian cohort with disorders of the frontotemporal lobar degeneration-amyotrophic lateral sclerosis spectrum: a gene identification study. Lancet Neurol 2012;11:54-65. [PubMed] [CrossRef]

15. Olney RK, Murphy J, Forshew D et al. The effects of executive and behavioral dysfunction on the course of ALS. Neurology 2005; 65: 1774-7. [PubMed] [CrossRef]

16. Hu WT, Seelaar H, Josephs KA et al. Survival profiles of patients with frontotemporal dementia and motor neuron disease. Arch Neurol 2009; 66:1359-64. [PubMed] [CrossRef]

17. Chiò A, Borghero G, Restagno G et al. Clinical characteristics of patients with familial amyotrophic lateral sclerosis carrying the pathogenic GGGGCC hexanucleotide repeat expansion of C9ORF72. Brain 2012; 135: 784-93. [PubMed] [CrossRef]

18. de Carvalho M, Swash M. Amyotrophic lateral sclerosis: an update. Curr Opin Neurol 2011; 24:497503. [PubMed] [CrossRef]

19. Massman PJ, Sims J, Cooke N et al. Prevalence and correlates of neuropsychological deficits in amyotrophic lateral sclerosis. J Neurol Neurosurg Psychiatry 1996; 61: 450-5. [PubMed] [CrossRef]

20. Ringholz GM, Appel SH, Bradshaw M et al. Prevalence and patterns of cognitive impairment in sporadic ALS. Neurology 2005; 65: 586-90. [PubMed] [CrossRef]

21. Rosen DR, Siddique T, Patterson $\mathrm{D}$ et al. Mutations in $\mathrm{Cu} / \mathrm{Zn}$ superoxide dismutase gene are associated with familial amyotrophic lateral sclerosis. Nature 1993; 362: 59-62. [PubMed] [CrossRef]

22. Fecto F, Siddique T. Making connections: pathology and genetics link amyotrophic lateral sclerosis with frontotemporal lobe dementia. J Mol Neurosci 2011; 45: 663-75. [PubMed] [CrossRef]

23. Boeve BF, Boylan KB, Graff-Radford NR et al. Characterization of frontotemporal dementia and/or amyotrophic lateral sclerosis associated with the GGGGCC repeat expansion in C9ORF72. Brain 2012; 135: 765-83. [PubMed] [CrossRef]

24. Majounie E, Renton AE, Mok K et al. Frequency of the Cgorf72 hexanucleotide repeat expansion in patients with amyotrophic lateral sclerosis and frontotemporal dementia: a cross-sectional study. Lancet Neurol 2012; 11:323-30. [PubMed] [CrossRef]

25. Cooper-Knock J, Hewitt C, Highley JR et al. Clinico-pathological features in amyotrophic lateral sclerosis with expansions in C9ORF72. Brain 2012; 135: 751-64. [PubMed] [CrossRef]

26. Hsiung GY, DeJesus-Hernandez M, Feldman HH et al. Clinical and pathological features of familial frontotemporal dementia caused by $\mathrm{C}_{9 \mathrm{ORF}} 2$ mutation on chromosome 9p. Brain 2012; 135: 709-22. [PubMed] [CrossRef]

27. Ince PG, Highley JR, Kirby J et al. Molecular pathology and genetic advances in amyotrophic lateral sclerosis: an emerging molecular pathway and the significance of glial pathology. Acta Neuropathol 2011; 122: 657-71. [PubMed] [CrossRef]

28. Murray ME, DeJesus-Hernandez M, Rutherford NJ et al. Clinical and neuropathologic heterogeneity of c9FTD/ALS associated with hexanucleotide repeat expansion in C9ORF72. Acta Neuropathol 2011; 122: 673-90. [PubMed] [CrossRef]

29. Fecto F, Siddique T. UBQLN2/P62 cellular recycling pathways in amyotrophic lateral sclerosis and frontotemporal dementia. Muscle Nerve 2012; 45: 157-62. [PubMed] [CrossRef]

30. Brettschneider J, Van Deerlin VM, Robinson JL et al. Pattern of ubiquilin pathology in ALS and FTLD indicates presence of C9ORF72 hexanucleotide expansion. Acta Neuropathol 2012;123: 825-39. [PubMed] [CrossRef]

31. Fong JC, Karydas AM, Goldman JS. Genetic counseling for FTD/ALS caused by the C9ORF72 hexanucleotide expansion. Alzheimers Res Ther 2012; 4: 27. [PubMed] [CrossRef]

32. Frank SA. Evolution in health and medicine Sackler colloquium: Somatic evolutionary genomics: mutations during development cause highly variable genetic mosaicism with risk of cancer and neurodegeneration. Proc Natl Acad Sci U S A 2010; 107 (suppl 1): 1725-30. [PubMed] [CrossRef] 
Publisert: 11. februar 2014. Tidsskr Nor Legeforen. DOI: 10.4045/tidsskr.13.0049

Mottatt 31.8. 2012, første revisjon innsendt 13.1. 2013, godkjent 28.10. 2013. Redaktør: Kristin Viste.

(C) Tidsskrift for Den norske legeforening 2023. Lastet ned fra tidsskriftet.no 26. april 2023. 